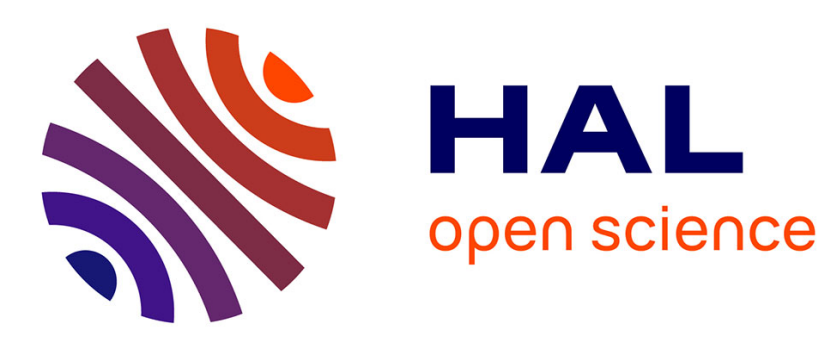

\title{
New Evidence for Nicholas Aston's Principia on the Sentences: Basel, UB, A.X.24
}

Monica Brinzei

\section{To cite this version:}

Monica Brinzei. New Evidence for Nicholas Aston's Principia on the Sentences: Basel, UB, A.X.24.

Chôra. Revue d'études anciennes et médiévales, In press, 18. hal-02505939

\section{HAL Id: hal-02505939 \\ https://hal.science/hal-02505939}

Submitted on 11 Mar 2020

HAL is a multi-disciplinary open access archive for the deposit and dissemination of scientific research documents, whether they are published or not. The documents may come from teaching and research institutions in France or abroad, or from public or private research centers.
L'archive ouverte pluridisciplinaire HAL, est destinée au dépôt et à la diffusion de documents scientifiques de niveau recherche, publiés ou non, émanant des établissements d'enseignement et de recherche français ou étrangers, des laboratoires publics ou privés. 
New Evidence for Nicholas Aston's Principia on the Sentences: Basel, UB, A.X.24*

\author{
Monica BRINZEI \\ (IRHT, Paris)
}

Nicholas Aston's lectures on the Sentences of Peter Lombard, delivered at Oxford around 1350, are crucial for tracing reactions to the freshly released De causa Dei of Thomas Bradwardine and a unique piece of evidence for doctrinal tendencies at Oxford just before Wycliff $^{1}$. Although historical and doctrinal elements converge to demonstrate the significance of this author for our knowledge of Oxonian philosophy in the later Middle Ages, not much scholarly attention has been devoted to his surviving writings. Joel L. Bender's still unpublished $\mathrm{PhD}$ dissertation of $1979^{2}$ was an ambitious attempt, after Damasus Trapp first effort ${ }^{3}$, to present Aston's philosophical thought, but it was two magisterial articles by Zenon Kaluza, published in Archives d'histoire doctrinale et littéraire du Moyen Âge and recently reprinted in his collected articles from $2013^{4}$, that revealed the pivotal role that Aston played in introducing Oxford thought to Paris. Kaluza discussed at length the material circulation of Aston's Sentences questions, listing manuscripts Oxford, Oriel College $15(\mathbf{O})$ and Worcester, Cathedral Library F. 65 (W) along with the valuable notebook of Etienne Gaudet, who summarized some of Aston's texts in manuscript Paris, Bibliothèque nationale de France, lat. 16535 (P). Kaluza did not discuss a third manuscript, Cambridge, Gonville and Caius College 290/682 (C), described by Bender, but he added a fifth manuscript, identified by Katherine $\mathrm{H}$. Tachau $^{5}$ in codex Firenze, Biblioteca Nazionale, conv. Soppr. B $6910(\mathbf{F})$. The presence of Aston's Sentences questions in Florence illustrates the voyage of Oxonian ideas outside England and France. This paper adds another stage to this Rezeptionsgeschichte by identifying an anonymous text stemming from the University of Vienna as a new copy of Nicholas Aston's questions on Lombard's Sentences.

\footnotetext{
* This research was supported by ERC consolidator grant DEBATE-ERC CoG 771589. I thank for assistance my colleagues Adinel Dinca from the RISE project and Chris Schabel from the DEBATE project. I am grateful to Luciana Cioca, who checked for me in situ my notes on Cambridge, Gonville and Caius College ms. 290/682 and Alexandra Baneu for her comments.

${ }^{1}$ See for example the chapter 'Trends in Speculation at Oxford, 1350-1370', in J.A. Robson, Wyclif and the Oxford Schools. The Relation of the 'Summa de Ente' to Scholastic Debate at Oxford in the Later Fourteenth Century, Cambridge, Cambridge University Press, 1961, pp. 97-112 and Z. Kaluza, Études doctrinales sur le XIVe siècle. Théologie, Logique, Philosophie, Paris, Vrin, 2013, p. 54.

2 J.L. Bender, Nicholas Aston: A Study in Oxford Thought after the Black Death, PhD University of WisconsinMadison, 1979. W.J. Courtenay, Bender's supervisor, also dedicated some pages to Aston in his Schools and Scholars in Fourteenth-Century England, Princeton, NJ, Princeton University Press, 1987, pp. 340-347 passim.

${ }^{3}$ D. Trapp, “Augustinian Theology of the Fourteenth Century: Notes on Editions, Marginalia, Opinions and Book-Lore', Augustiniana 6 (1956), pp. 147-265, here p. 152.

${ }^{4}$ Z. Kaluza, 'L'œuvre théologique de Nicolas Aston. Étude du texte et des manuscrits de ce professeur à Oxford du milieu du XIV ${ }^{\mathrm{e}}$ siècle", Archives d'histoire doctrinale et littéraire du Moyen Age 45 (1978), pp. 45-82, and "L'œuvre théologique de Richard Brinkley, OFM", Archives d'Histoire doctrinale et littéraire du Moyen Age 56 (1989), pp. 169-273. These two articles are republished in his Études doctrinales sur le XIV siècle, pp. 53-200.

${ }^{5}$ I am grateful to Katherine H. Tachau, who shared with me her notes on Aston, in which she identified manuscript F in 4 October 1984 via G. Pomaro, "Censimento dei manuscritti della Biblioteca di S. Maria Novella", Memorie Domenicane 11 (1980), pp. 325-470. She never published her findings on Aston. Concerning this manuscript see G.C. Garfagnini, M.R.P. Sturlese, G. Pomaro, Catalogo di manoscritti filosofici nelle biblioteche italiane 3, Firenze, Firenze, Leo S. Olschki, 1982, pp. 15-16.
} 
Codex Basel, Universitätsbibliothek, A.X.24 is a miscellaneous collection of theological treatises that the Dominican Henricus of Rinfeldia brought from Vienna to Basel ${ }^{6}$. The Basel convent of the Friars Preached had sent Rinfeldia to Vienna to read his Sentences at the new Faculty of Theology. In preparation for his doctorate, in the period 1389-1400 Rinfeldia conscientiously attended public disputations, which he recorded in his notebooks, for example manuscript Basel, BU, A.X.44. In parallel with these notes, the current subject of investigation of the RISE project in $\mathrm{Cluj}^{7}$, Rinfeldia also assembled various theological treatises that he annotated in his own hand. Codex Basel, BU A-X- $24^{8}$ contains one of these collections, the first folio of which, added when the manuscript was bound, contains the following list of Contenta huius libri ${ }^{\text {: }}$ :

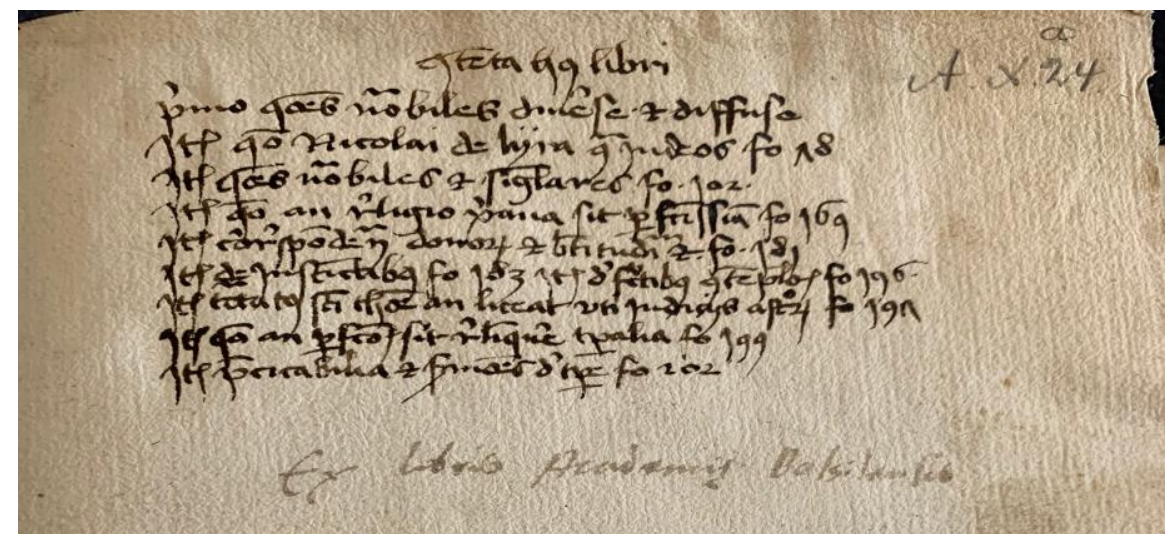

Text 1: Primo: questiones notabiles diverse et diffuse (1-73v)

Text 2: Item questio Nicolai de Lyra contra Iudeos fo 78 (deest $)^{10}$

Text 3: Item questiones notabiles et singulares fo $102(74 \mathrm{r}-140 \mathrm{v})^{11}$

\footnotetext{
${ }^{6}$ For a short biography of this author see M. Brînzei, 'Unknown Fragments of Petrus de Treysa in the Codex Basel, Universitätsbibliotek A-X-44', Chora 14 (2016), pp. 285-293.

${ }^{7}$ A presentation of the project can be found on the website www.rise-ubb.ro. See also the report by Edit Lukacs of a first workshop held in Cluj-Napoca in 2019: "Decoding a Medieval Notebook: The Case Study of MS Basel, Universitätsbibliothek, A-X-44", Bulletin de Philosophie Médiévale 2019 (forthcoming).

${ }^{8}$ A detailed codicological description of the manuscript will be published by RISE project.

${ }^{9}$ The foliation introduced by 'fo' is the one indicated by the tabula, and the one that I introduce in square brackets is the one following the modern numbering.

${ }^{10}$ This text is missing from the manuscript and contained the Tractatulus ad quendam Iudaeum ex verbis evangelii secundum Matthaeum contra Christum nequiter arguentem composed by Nicholas of Lyre in 1334 as a response to the anti-Jews polemic launched in 1309 in the Questio de adventu Messie. The Tractatulus is a defense of the Gospels against Jewish disbelief in the New Testament. Although the Tabula indicates the text, this one is missing and probably has been torn from the codex. In the initial composition of the codex this missing treatise ran from fo $79 \mathrm{r}$ to fo $101 \mathrm{v}$.

${ }^{11}$ This is an interesting series of ten questions related to the Vienna Faculty of Theology and connected to the topics of Sentences' commentaries. Actually, the titles of nine of these ten questions are also in Basel, BU, A-X44. Although the two manuscripts share the titles of these questions, the content is not the same and a comparison of the texts in the two codices shows that the size and the content of each question is different. This parallel is under investigation right now by the team of project RISE. This codicological unit also contains a copy of the Questio de anima Christi of Conrad of Ebrach. Another copy of this text is found in manuscript Basel, BU, A-VI-22. According to manuscript Munich, Clm 27034, this question is the resumpta of Conrad of Ebrach and it should be added here that this codex also contains some folios in Rinfeldia's hand. This allows us to conclude that the three copies of this question in Vienna are connected with Rinfeldia. See on Conrad of Ebrach M. Brinzei, C. Schabel, "Les cisterciens et l'université: Le cas du commentaire des Sentences de Conrad d'Ebrach (†1399)", in A.-M. Turcan-Verkerk, D. Stutzmann, Th. Falmagne, P. Gandil (eds.), Les cisterciens et leurs bibliothèques, Turnhout, Brepols, 2018, pp. 453-486. Manuscript Munich, Clm 27034 is discussed, but not in connection with Conrad's resumpta, in C. Schabel, M. Brinzei, M. Maga, "The Golden Age of Theology at
} 
Text 4: Item questio an religio Christiana sit perfectissima fo $169(141 \mathrm{r}-152 \mathrm{v})^{12}$

Text 5: Item correspondentia donorum et beatitudinum fo $181(153 \mathrm{r}-154 \mathrm{v})^{13}$

Text 6: Item de instinctibus fo $183 /(155-166 \mathrm{v})^{14}$

Text 7: Item de factibus contemplationis fo 196 (168r-v)

Text 8: Item tractatus Sancti Thome an liceat uti iudicii astronomorum fo 197 (169r$170 \mathrm{v})$

Text 9: Item questio an perfectionis sit relinquere temporalia fo 199 (171r-172v)

Text 10: Item predicabilia et sermones de tempore fo $202(173 \mathrm{r}-210)^{15}$

The first entry in this Tabula consists of a list of questions on the Sentences that I propose to identify with the so-called Articuli of Nicholas Aston stemming from his lectures on the Sentences. In the appendix to this paper I have compiled a list of Aston's question titles along with references to the questions listed in the other manuscripts of Aston's texts as the first piece of evidence for the authenticity of the questions in the Basel manuscript (B). I have also collated some fragments from $\mathbf{B}$ with the other manuscripts of Aston and with what Bender edited in order to solidify the attribution.

Besides the attribution of this text to Nicholas Aston, the present paper aims to determine how much of Aston's so-called Articuli stems from his principia debates with his socii. Bender noted that Aston's style should be understood in the context of the Oxford trend of commenting on Lombard, which Trapp characterized as the 'English-essay-style"16. The varying contents of the manuscripts and even the composition of each question pose some problems, and neither Bender nor Kaluza managed to clarify in full the nature and chronology of this set of questions on the Sentences. Perhaps different assumptions will prove more fruitful. If we read at least part of the text, if not the whole, as a principium, more aspects of Aston's style can be deciphered. Thus the 'welter of arguments and counter-arguments that he brings to any issue ${ }^{17}$ an his non-informative 'response per se to any of the articles' could simply reflect a typical attitude in the principia text current in Aston's day, and the parallel principia of Jean Regis and James of Eltville ${ }^{18}$ provide clues to better understand Aston's text. Moreover, since two of the manuscripts preserve the same text, Kaluza proposed labels to explain this variation, calling $\mathbf{O}$ and $\mathbf{W}$ respectively a reportatio and a ordinatio. (He did not investigate $\mathbf{C}$ and $\mathbf{F}$.) When we associate Aston's texts to the practice of principia, however, we arrive at another explanation for the differences between the manuscripts.

Prague: Prague Sentences Commentaries, ca. 1375-1381, with a Redating of the Arrival of Wycliffism in Bohemia", Historia Universitatis carolinae Pragensis 55 (2015), pp. 19-40.

${ }^{12}$ Actually, under this title we can identify some fragments from the Summa Hallensis, 4, De sacramento Eucharistie.

${ }^{13}$ Bender, Nicholas Aston: A Study in Oxford Thought, p. 7.

${ }^{14}$ In this part of the text we read some fragments extracted from Henricus de Frimaria, Tractatus de quattuor instinctibus. This is not a surprise, since the De quattuor instinctibus divino, angelico, diabolico, et humano ("About the four instincts - divine, angelic, diabolic and human") was a very popular text, being an original discussion of the discernment of spirits, surviving in over one hundred and fifty Latin manuscripts, as well as in eighteen Dutch and German versions. An edition of this text has been done by A Zumkeller, T.G. Aarnock, Der Traktat Hienrichs von Friemar über die Unterscheidung der Geister. Lateinsch-mittelhochdeutsche Textausgabe mit Untersuchungen, Würzburg, 1977.

${ }^{15}$ Actually, the Tabula does not mark the fact that between $\mathrm{f} .181 \mathrm{r}$ and $\mathrm{f} .210 \mathrm{v}$ we find a variety of excerpte.

${ }^{16}$ Trapp, "Augustinian Theology", p. 231.

${ }^{17}$ Bender, Nicholas Aston: A Study in Oxford Thought, p. 27.

${ }^{18}$ See the case studies of these two autors in M. Brinzei, "When Theologians play Philosopher: A Lost Confrontation between James of Eltville and His socii on the Perfection of Species and Its Infinite Latitude", in M. Brinzei, C. Schabel (eds.), The Cistercian James of Eltville († 1393). Author in Paris and Authority in Vienna, (Studia Sententiarum, 3), Turnhout, Brepols, 2018, pp. 43-77. 
When Kaluza and Bender were working on Aston in the late 1970s, not much was generally known about principia $^{19}$. Kaluza proposed to identify the first question from $\mathbf{W}$, or what we find in the manuscripts as Questio primo die, with the "principium du livre premier du commentaire de Nicolas Aston" and added that 'Je l'appelle aussi prologue" ${ }^{20}$. The latter remark confuses matters, since prologues and principia belong to two very different genres and conflating these terms hinders efforts to discern the nature of the text. Kaluza also goes a bit too far when he states that "il nous est, en conséquence, impossible de penser que ce principium reste inachevé", since this exercise "était toujours solidement préparée et bien à l'avance" 21 . It is true that the preparation was quite solid, but one cannot deny that principia also circulated in unfinished versions. Although Kaluza and Bender went to great lengths to understand and to explain the nature of the text, its chronology and its composition, both overlooked certain details that suggest a different line of interpretation. Taken together, the following examples indicate that at least a part of what Kaluza reconstituted as Book I ${ }^{22}$ should be read as notes from the debates in which Aston participated during the four principia before reading the books of the Sentences:

(1) The text abounds in references to socii, the fellow bachelors with whom the Aston engaged in debate during the principia. We usually witness two tendencies in principia. Some authors are very open with personal information about their socii, quoting their names and their affiliations or even providing details about their origins. The second attitude is when the authors are very discreet about their socii, making only vague comments. Aston belongs to the second category, citing his socii like this: patet per magistrum reverendum qui tertio loco intravit ad Sententias isto anno (p. 210), contra istum magistrum arguitur (p. 210), ratio sua stat in isto (p. 211), probat opinionem suam et respondet ad argumenta sua (p. 211), quia magister reverendus negat antecedens (p. 215), in ista materia dicit quidam magister reverendus (p. 219), Istis visis dico quod si istud intelligas ...dico quod sicut iste discursus est paralogismus (p. 237) ${ }^{23}$ This manner of referring to socii can be the source of misunderstanding ${ }^{24}$. Damasus Trapp proposed identifying some of his socii with the Carmelite Osbert Pickingham and Thomas Buckingham ${ }^{25}$, but so far no clear reference has been found among Aston's quotations. Although I have not been able to identity Aston's socii, there are recurrent mentions of them in his Articuli. Through the inspection of surviving questions on the Sentences and principia from same authors, it becomes apparent that references to socii are common in principia but normally absent in questions on the four books. There is no reason to believe that Aston's case is unusual, so the high number of references to socii suggest that the text stems from principia.

(2) The text can be easily read as a dialogue because of the libido arguendi. The title libido arguendi is taken from the principia debate between the Benedictine Pierre Roger (later Clement VI) and the Franciscan Francis of Meyronnes in Paris in 1320-21, characterizing the succession of arguments that helps sketch how an idea is defended: pro, contra, answer to the

\footnotetext{
${ }^{19}$ Except for the pioneering article of Trapp from 1956, "Augustinian Theology", the first scholar who dedicated some attention to this genre was F. Ehrle, Der Sentenzenkommentar Peters von Candia, des Pisaner Papstes Alexanders V.: ein Beitrag zur Scheidung der Schulen in der Scholastik des 14. Jahrhunderts und zur Geschichte des Wegestreites, Münster, Verlag der Aschendorffschen Verlagsbuchhandlung, 1925, at pp. 39-56.

${ }^{20}$ Kaluza, Études doctrinales sur le XIVe siècle, p. 65.

${ }^{21}$ Kaluza, Études doctrinales sur le XIVe siècle, p. 65.

${ }^{22}$ Kaluza, Études doctrinales sur le XIVe siècle, p. 63.

${ }^{23}$ The reference to pages sent to Bender's edition published as an appendix to his $\mathrm{PhD}$.

${ }^{24}$ Robson tried to identify one of the socii as Ockham, because the socius' doctrinal position against the real status of relations is close to that of Ockham: Robson, Wyclif and the Oxford Schools, pp. 107-107.

${ }^{25}$ Trapp, "Augustinian Theology", p. 229. On the relation between Aston and Osbert Pickingham see also W.J. Courtenay, Adam Wodeham. An Introduction to his Live and Writings, Leyden, Brill, 1978, p. 122.
} 
contra, answer to the answer to the contra ${ }^{26}$ and that sometime look like an arguing for the sake of arguing. This is common in principia, unlike in questions on the Sentences, where one usually finds pro and contra arguments not in the succession of a dialogue, but more like a quaestio. One can follow the libido arguendi in Aston's text ${ }^{27}$, which is cast in the form of a confrontation between two opponents, perceptible in the succession of paragraphs. The verb's voice indicates the position of each of the socii: one speaks actively as arguo and the other's position is introduced with arguitur. The waltz between the two persons of the verb arguere in Aston's questions and the constant switch from arguo to arguitur is very similar to what we find in the majority of principia that we have identified so far. To this we can add the obvious traces of dialogue: ... Quando tu ultra ponis quod aliquid erit, quero a te, numquid tu ponis aliquid erit stante primo casu posito, ut pote quod nihil est, vel non... (p. 281) or ... quando tu ponis... quero a te, numquid ponis (p. 280).

(3) The use of logic as a weapon to attack the position of a socius: visa opinione et eius ratione, probo eam esse deceptam per fallaciam figure dictionis (p. 220), pro prima ratione sua... dico quod iste est paralogismus (p. 220), decipitur per fallaciam figure dictionis (p. 119) is also a commonplace in principial debates ${ }^{28}$. The frequent invocation of logical rules is a technical aspect of principia: Igitur ex opposito sequitur oppositum (p. 373), and one also finds absurd syllogisms: Deus scit hominem non esse asinum; et qualitercumque Deus scit, sic est; igitur sic est quod homo non est asinus; igitur hominem non esse asinum est; et non a se, igitur a Deo; et per consequens alicuius non esse Deus est causa (p. 474). A whole study could be devoted to this subject, but many examples ${ }^{29}$ reinforce the idea that the use of logic as a tool in principial argumentation was particularly important.

(4) Recent research has shed new light on the principia genre, identifying more technical details characteristic of the practice of principia that also appear in Aston's texts. In particular, case-studies on principia have revealed aspects common to many principia. Principia circulated in unfinished or unedited form ${ }^{30}$, the same principia were reported in two or more redactions ${ }^{31}$, within the manuscript tradition one finds varying versions of the debate linked to different stages of redaction ${ }^{32}$, principia circulated as notebooks, collections of theses or recycled material of principia in articuli, as in the case of the Sex articuli of Robert Holcot. Holcot's articuli are, in fact, as it has been recently demonstrated, replicationes gathered from his confrontation with some of his colleagues. Among them some are steaming

\footnotetext{
${ }^{26}$ François de Meyronnes, Pierre Roger, Disputatio (1320-1321), J. Barbet (ed.), préface P. Vignaux, Paris, Vrin, 1961, p. 91.

${ }^{27}$ This formula is used by one of the socii of Francis of Mayronis, see François de Meyronnes, Pierre Roger, Disputatio (1320-1321), p. 99: "Ista sunt arguta per istos venerabiles socios. Salva tamen venerabilum sociorum reverentia, ista videntur michi arguta sola libidine arguendo".

${ }^{28}$ For another exemple of the use of fallacie see M. Brinzei, "Nouveau témoignage de la doctrine d'Onofre de Florence", Archives Doctrinale d'Histoire et Littérature du Moyen Age 68 (2020), forthcoming.

${ }^{29}$ In this respect we can add a remark of Bender, Nicholas Aston: A Study in Oxford Thought, p. 104 : “ Aston's style of argumentation is clearly exemplified by the above proof. We can almost imagine him leading his nodding opponent down the path to self-contradiction. If the consequence is not valid, it then follows that, in spite of God's existence, a proposition signifying 'Deum non esse' does not entail a contradiction. Let such a proposition be A, and let its contradictory be called B. Since God exists, A is false ".

${ }^{30}$ See the situation with Jean of Regis, where the four principia are not finished and at the end we just find a notebook with fragments of text from his socii.

${ }^{31}$ See the same confrontation between Jean Regis and James of Eltville in Paris in 1369 reported in two different manuscripts from two distinct positions, one of Eltville and one of Regis. See Brinzei, 'When Theologians play Philosopher', pp. 43-77.

${ }^{32}$ See the situation with Jean Mirecourt: among the ten copies of his principia, some variants contain more personal details, namely concerning the confrontation with his socii, especially the manuscript Metz, Bibliothèque Nationale 211.
} 
from principial debates ${ }^{33}$. It is possible that the articuli was a common textual-division-unit specific to Oxford principial debates ${ }^{34}$. As discussed above, articuli is a confusing term here, since it seems to be used for two different things. First, an articulus is a general question proposed for debate with the socii. Second, each articulus-question is normally divided into three articuli, which are subdivided into conclusions and then propositions and corollaries. At this level an articulus is a textual unit.

The titles of Aston's questions are identified in some manuscripts as Articuli. Manuscript $\mathbf{B}$ is very precise and consistent with this terminology. We do not have this denomination at the University of Paris, so it could be particular to Oxford. At the same time, we must keep in mind that there were two uses of the term articuli, one corresponding to the titles of the questions denoting the theses to be debated and the other referring to parts of the divisions of questions. Aston's questions were normally divided into three articuli, although the manuscripts are not always complete and may only contain one article, while announcing three $^{35}$. For example, the first question announces in the division of the question the three articuli that divide the question, but in the manuscripts we find only two of them developed, with the second article in $\mathbf{O}$ and $\mathbf{W}$ becoming the first article in $\mathbf{B}$. This shows that the transmission of the text was not uniform and that different versions from different redactional stages circulated. Even the testimony in $\mathbf{P}$, via Gaudet's notes, contains more material than the list of questions from $\mathbf{O}$ and $\mathbf{W}^{36}$. What we should add here is that the list of questions from the Basel manuscript is so far the most complete among all the witnesses to this text. This manuscript includes four more questions, numbers 11 and 14-16 according to the appendix, that are not in any other manuscript containing Aston's questions. The questions are interspersed among those that are certainly by Aston and stylistically it is possible to establish some connection with Aston's writings with consistency in the vocabulary ${ }^{37}$, but probably a deeper analysis will uncover more evidence in the future.

One last issue needs to be addressed: the circulation of this material in Vienna. Since the section with Aston's questions in the manuscript can be identified as an individual codicological unit, this could be one of the texts that German students in Paris, such as Henry of Langenstein, Henry Totting of Oyta, Peter of Gelria and Conrad Zollern, brought with them once they were forced to leave Paris during the Schism because of their adherence to Urban VI in Rome rather than Clement VII in Avignon. The presence of some watermarks in the paper employed for this set of questions reveals that the paper of this section of Basel, BU, A.X.24 was produced in Vienna, where the codex was thus probably copied. The manuscript could be the copy of a document imported from Paris, but Prague should also be taken in consideration as a possible source. At the end of the fourteenth century, Prague

\footnotetext{
${ }^{33}$ Some new articles converged in the conclusion that Holcot's Ariculi contain fragments from his principia. See P. Bermon, "A la recherché des Principia aux Questiones sur les Sentences de Robert Holkot, O.P. († 1349)", in M. Brinzei, W. Duba (eds.), Principia between Institutional Exercice and Philosophical Debate, Turnhout, Brepols, 2020, forthcoming; C. Schabel, "Ockham, the Principia of Holcot and Wodeham, and the Myth of the Two-Year Sentences Lecture at Oxford", Recherches de Theologie et Philosophie Medievale 2020, forthcoming; C. Schabel, "Robert Holcot's Assorted Theological Questions and His Principial Debate with Adam Wodeham over Merit and Grace", forthcoming.

${ }^{34}$ We should call attention here to another manuscript containing principia from the Oxford milieu that are also divided into articuli and subarticuli, Munich, Clm 27304, which still needs further investigation, although Trapp dedicated a study to it in D. Trapp, "Clm 27034. Unchristened Nominalism and Wycliffite Realism at Prague in 1381", Recherches de théologie ancienne et médiévale 24 (1957), pp. 320-260.

${ }^{35}$ See the example of the first question. Kaluza analyzed the situation in Études doctrinales sur le XIVe siècle., pp. 57-58 and also the edition of Bender, Nicholas Aston: A Study in Oxford Thought, pp. 203-258.

${ }^{36}$ Based on Kaluza's research, lists the material from $\mathbf{P}$ that is not in the other manuscripts: Bender, Nicholas Aston: A Study in Oxford Thought, pp. 20-22. The edition of fragments from $\mathbf{P}$ are in Kaluza, Etudes doctrinales sur le XIVe siècle, pp. 77-86.

${ }^{37}$ See below, footnote XXX.
} 
students had a very dynamic exchange with Oxford $^{38}$ and it is possible that they did not introduce just Wycliffite texts into Eastern Europe, but also other doctrinal material. In fact, codex Munich, Bayerische Staatsbibliothek, Clm 27034 also contains some principial questions of a student from Prague educated in Oxford, and this manuscript was probably in circulation in Vienna' theological milieu. Besides this, the codex also contains some theses that Trapp suggested ${ }^{39}$ might be linked to Aston's questions. This may constitute interesting new evidence for the reception of Oxonian philosophy in Vienna.

Manuscript Basel, BU A-X-24, is thus an interesting testimony to the circulation of Nicholas Aston's text on the Sentences in Vienna at the end of the $14^{\text {th }}$ century. Henry of Rinfeldia brought the codex to Basel when he returned from studying in Vienna. The manuscript definitely requires more investigation, with a transcription and a comparison with the other Aston witnesses, in order to clarify the structure and the transmission of this text.

\section{Appendix:}

New list of manuscripts of Aston's questions stemming from his lectures on the Sentences:

B Basel, Universitätsbibliotek, A.X.24, ff. 1-73v

C Cambridge, Gonville and Caius College ms. 290/682

F Firenze, Biblioteca Nazionale, conv. Soppr. B 6910 , col. 3-178

O Oxford, Oriel College 15, ff. 210v-222rb

$\mathbf{P} \quad$ Paris, Bibliothèque nationale de France, lat. 16535, ff. $118 \mathrm{r}-122 \mathrm{r}^{42}$

W Worcester, Cathedral Library F. 65, ff. 43ra-63va ${ }^{43}$

\footnotetext{
38 F. Šmahel, "Wyclif's Fortune in Hussite Bohemia", in Die Prager Universität im Mittelalter. Charles University in the Middle Ages, Brill, Leiden, 2007, pp. 467-89, at p. 272; M. Brînzei, "Stanislaus of Znojmo and the Arrival of Wyclif's Remanence Theory at the University of Vienna", in K. Ghosh, P. Soukup, M. Bose, E. Solopova (eds.), Wycliffism and Hussitism: Contexts, Methods, Perspectives, Turnhout, Brepols, forthcoming.

${ }^{39}$ Trapp, “Clm 27034. Unchristened Nominalism and Wycliffite Realism”, p. 347.

40 The manuscript opens with a tabula containing a list of 20 numbered titles and the following mention on the opening pastedown, which help to trace his history: "Iste liber concessus est fratri Dominico Johannis, die 4 mensis Iulii, anno Mo CCCCo XXVIo Proprietate reservata Florentino conventui".

${ }^{41}$ This codex contains only 12 questions of Aston's sentential material, as it is indicated on f. 201rb: "Iam sequuntur 12 questiones magistri Nicolai Aston Oxonie disputate". A transcription of this list is in Trapp, “Augustinian Theology”, pp. 230, and Kaluza, Études doctrinales sur le XIVe siècle, pp. 55-56.

${ }^{42}$ This witness is actually just a summery by Etienne Gaudet and can be found in one of the codices of his collection of notebooks. The text from ff. 118r-122r, entitled in the codex Astona, is edited by Kaluza in his book Etudes doctrinales sur le XIVe siècle, pp. 77-86. This edition reveals traces of four more titles that are not in any of the other codices. This material could be titles of questions or articles from other questions.

${ }^{43}$ For the question list in this manuscript see Kaluza, Études doctrinales sur le XIVe siècle., pp. 63-64. In his transcription Kaluza attributes the question Utrum quilibet homo concupiscencialiter propagatus concipitur in peccato originali (f. 63va-b) to Aston. Q. 16 in Kaluza's list does not end on f. 63vb but on f. 71va and should not be attributed to Aston since it is q. 7 of Book 2 of the Sentences of Richard FitzRalph. For the tabula of questions of FitzRalph see M. Dunne, "Richard FitzRalph's Lectura on the Sentences", in Ph.W. Rosemann (ed.), Medieval Commentaries on the Sentences of Peter Lombard, vol. II, Leyden, Brill, 2010, pp. 405-437, here p. 412. This is also confirmed by the catalogue A Descriptive Catalogue of Medieval Manuscripts in the Worchester Cathedral Library, by R.M. Thomas, coll. M. Gullick, Cambridge, D.S. Brewer, 2001, pp. 40-41.
} 
The tabula below is a transcription of the questions found in Basel, UB, A.X.24. In footnotes I indicate the philological variants in the text of $\mathbf{B}$. At the end of each title I list the foliation of the other five codices ${ }^{44}$ and when a question is missing I use the sign $\varnothing$. This will highlight the fact that $\mathbf{B}$ contains questions 11 and 14-16, which are missing in all other manuscripts. After the sigla of the manuscripts I repeat the numbering established by Kaluza in the tabule that he transcribed from $\mathbf{O}$ and $\mathbf{W}$. In the case of $\mathbf{F}$ I reproduce the numbering from the tabula which is opening the codex, where the questions are numbered. I add at the end of the tabula from $\mathbf{B}$ a paragraph with the added questions from $\mathbf{F}$. After the foliation I give the pages of Bender and Kaluza's editions ${ }^{45}$.

\section{Tabula Quaestionum from Basel, BU, A.X.24}

1.Questio tractanda est ista: Utrum veritatem increatam immediate et contingenter veritatem ad extra producere fundamentum sit fidei Christiane. (B: ff. 1r-6r; C12: pp. 406a, 407b ${ }^{46}$; F16: col. 159-168 ${ }^{47}$; O1 ${ }^{48}$ : ff. 210va-212ra; P11: f. 119r; W Prol.: ff. 43ra-45rb; Bender: pp. 203-258, (Additiones) pp. 260-274)

2. Primus articulus est ${ }^{49}$ iste: Utrum aliqua propositio significans precise Deum non esse contradictionem includit. (B: ff. 6r-9v; C1: pp. 18b-21a; F1: col. 3*-11; O11: ff. 220vb-221vb; P1: f. 118r; W Prol., art. 1: ff. 45rb-47ra; Bender: pp. 275-331; Kaluza: pp. 77-78)

3. Secundus articulus tractandus est iste: Utrum inter necesse esse et impossibile esse mediet possibile esse et loquitur de possibili quod non est necesse esse nec claudit contradictionem esse. (B: ff. 9v-12v; C2: pp. 21a-22b; F2: col. 11-24; O7: ff. 217ra218ra; P 9: f. 118v; W Prol., art. 2: ff. 47ra-48vb; Bender: pp. 332-371; Kaluza: p. 80)

4. Tertius articulus pertractandus sit iste ${ }^{50}$ : Utrum cuiuslibet futuritionis et preteritionis ${ }^{51}$ Deus sit causa. (B: ff. 13r-15r; C3: pp. 23a-24a; F3: col. 25-33; O8: ff. 218rb-vb; P2: f. 118r; W3: ff. 48vb-50ra; Bender: pp. 372-400; Kaluza: p. 78)

\footnotetext{
${ }^{44}$ The manuscript $\mathbf{C}$ is not foliated but paginated, and in the case of $\mathbf{F}$ the colums are numeberd.

${ }^{45}$ In the appendix to his $\mathrm{PhD}$ dissertation, Bender edited qq. 1-8 and 18 from the tabula edited here: Bender, Nicholas Aston: A Study in Oxford Thought, pp. 203-590 and Kaluza, Études doctrinales sur le XIVe siècle, pp. 77-86.

${ }^{46}$ According to Bender, there are some additions to the prologue in Cambridge, Conville \& Caius College 290/282, f. 406a et 407b, edited in his PhD, pp. 260-274.

${ }^{47}$ In the manuscript $\mathbf{F}$ the folia are not numbered, but the columns. This numbering is from 3 to 80 . From column $81 \mathrm{I}$ am numbering myself following the microfilm. The codex ends with blank folia. For this reason, since I did not been able to check the original it is possible to introduce some errors. The first folio has been ripped out and the text starts abruptly in column $3:$ "... tali propositione formaliter includente affirmatur aliquid de aliquo". This beginning can be identify in Bender's edition. See Bender, Nicholas Aston: A Study in Oxford Thought, p. 284.

${ }^{48}$ The title is slightly different in O: Utrum veritatem creatam poterit veritas <in>creata hypostatice sustentare. 49 est] et $a d d$. B

${ }^{50}$ Tertius-iste] Quia alias posui tales conclusiones - duas scilicet sequantes: Antichristus erit et tamen non est ita quod Antichristus erit, nec ab eterno fuit ita quod Antichristus erit; secunda fuit hec: qualitercumque poterit esse qualiter nunc non est, poterit incipere esse - ideo pro declaracione istarum sit iste articulus tractandus - this part is given by Kaluza as the beginning of the third article, but in $\mathbf{B}$ it is inserted in a different ink at the end of $\mathrm{f} .12 \mathrm{v}$ at the end of the second article: "Alias posui tales duas conclusiones sequentes: Antichristus est et tamen non est ita quod Antichristus erit, non est ab eterno fuit ita quod Antichristus erit. Secunda fuit hec: qualitercumque
} 
5. Quartus articulus pertractandus est iste: Utrum illud quod nunc est ${ }^{52}$ pro nunc sit possibile quod non sit nunc. (B: ff. 15r-18v; C4: pp. 24a-25b ${ }^{53}$; F4: col. 33-45; O9: ff. 218vb-219vb; P3: f. 118r; W4: ff. 50ra-51rb; Bender: pp. 401-437; Kaluza: p. 78)

6. Articulus quintus tractandus est iste: Utrum omne preteritum ${ }^{54}$ necessario sit preteritum. (B: ff. 18v-21r; C8: pp. 367a-370a; F9: col. 98-109; O5: ff. 214vb-215va; P8: f. 118v; W6: ff. 52va-53vb; Bender: pp. 438-470; Kaluza: pp. 79-80)

7. Sextus articulus tractandus est iste: Utrum privationes et negationes sint a Deo. $\left(\mathrm{B}^{55}\right.$ : ff. 21r-26r/27*; C7: pp. 365a-367a; F5: col. 45-62; O10: ff. 219vb-220vb; P4: f. 118r; W7: ff. 53vb-55vb; Bender: pp. 471-523; Kaluza: pp. 78-79)

8. Septimus articulus probandus est iste: Utrum certa previsio divina futurorum contingentium sit ex predestinatione voluntatis divine. (B: ff. 26r/27*-28r/29*; C6: pp. 152b-154a; F6: col. 62-72; O4: ff. 213vb-214vb; P5: f. 118v; W5: ff. 51rb-52va; Bender: pp. 524-548; Kaluza: p. 79)

9. Utrum aliqua sit distinctio que non est realis nec rationalis. (B: ff. $28 \mathrm{r} / 29^{*}-31 \mathrm{v} / 32 * ;$ C: $\varnothing$; F8: col. 84-98; O: Ø; P7: f. 118v; W8: ff. 55vb-57rb; Kaluza: p. 79)

10. Utrum dyabolum esse sit naturali ratione demonstrabile. (B: ff. 31v/32*-32/33*; C9: pp. 400a-402a; F10: col. 109-120; O2: ff. 212rb-213ra; P18: f. 120r; W13: ff. 61vb-63ra; Kaluza: pp. 83-84)

11. Utrum suppositum divinum posset sustentare ${ }^{56}$ naturam mere intellectualem pro re pro actionem angelice ruine. (B: ff. 32r/33*-34v/35*; F10bis: col. 110; C9bis: p. 400a; O2bis: f. 212rb; P18: f. 120r; W13bis: 61vb)

poterit esse qualiter nec non est, poterit incepere esse. Ideo pro declaratione istarum sit iste articulus tractandus" (this is as the end of art. 2 in $\mathbf{B}$ ).

${ }^{51}$ et preteritionis] add. sup. $l$. B

${ }^{52}$ est] et add. et del. $B$

${ }^{53}$ From page 25 the text of Aston is copied as a gloss added to a manuscript of the 13th century, probably a Parisian production, containing the Sentences of Peter Lombard. For the practice of the annotation of the Sentences of Lombard, see the $\mathrm{PhD}$ of $\mathrm{C}$. Angotti, Lectiones sententiarum : étude de manuscrits de la bibliothèque du collège de Sorbonne : la formation des étudiants en théologie à l'université de Paris à partir des annotations et des commentaires sur le Livre des Sentences de Pierre Lombard (XIIIe - XVe siècles), Ecole Pratique des Hautes Etudes, 2008.

${ }_{55}^{5}$ preteritum] non add. sed del. B

${ }^{55}$ From folio $27 \mathrm{r}$ the medieval numbering is off by one number, therefore in the following of the tabula I will reproduce the number as, e.g., f. $21 / 22 *$, with an asterisk indicating the medieval numbering.

${ }^{56}$ The title of this question uses the verb sustentare, which is often found in Aston's other questions. Perhaps this is a clue for attributing this question to Aston. The same verb is also in the title of a question in O: Utrum veritatem creatam poterit veritas <in>creata hypostatice sustentare. See above, note 39 . But another more convincing argument is that this question is referred to in $\mathrm{P}$ as an article of Q. 10: "Pro materia questionis tractat istum articulum: Utrum suppositum posset sustentare naturam mere intellectualem pro reparatione angelice ruine". Cf. Kaluza, Études doctrinales sur le XIVe siècle, p. 83. Examining question 10, "Utrum dyabolum esse sit naturali ratione demonstrabile", in all the manuscripts, one sees that after the In oppositum arguments, the question suddenly ends and one finds the title of Q.11 from Basel. It is possible that the model of these mss was faulty and omitted the remainder of Q. 10. Therefore, B perhaps had access to a better copy, not just more complete but also more coherent. In order not to introduce more confusion in the sequence and in the lists of questions of the other codices, I introduce this question as C9bis, F10bis, O2bis, W13bis. 
12. Utrum voluntas creata quodcumque obiectum potest (!) equaliter declinare sicut ${ }^{57}$ et in illud tendere. (B: ff. 34v/35*-37r/38*; C5: pp. 59a-63b; F11: col. 120-131; O: Ø; P10: f. 118v; W9: ff. 57rb-58vb; Kaluza: p. 80)

13. Utrum Antichristus poterit esse dyabolus incarnatus. (B: ff. 37r/38*-39r/40*; C: Ø; F15: col. 133-139; O12: ff. 222ra-rb; P15: f. 120r; W11: ff. 60va-91rb; Kaluza: p. 83)

14. Utrum Verbum divinum temporaliter incarnatum patribus in prophetiis multipharie revelatum suo immenso ac omnipotenti agere possit in entis latitudine duas species equalis perfectionis ad extra producere. (B: ff. 39r/40*-53v/54*; C: Ø; F: Ø; O: Ø; P: Ø; W: Ø)

15. Utrum per aliquod medium poterit deduci omnia citra Deum ab ipso produci, et intelligo conclusionem de medio sillogistico. (B: ff. 54r/55*-62r/63*; C: Ø; F: Ø; O: Ø; P: Ø; W: Ø)

16. Utrum eiusdem speciei omnes angeli sint creati. (B: ff. 62v/63*-64r/65*; C: $\varnothing ; \mathrm{F}$ : $\varnothing ; \mathrm{O}$ : $\varnothing ; \mathrm{P}: \varnothing ; \mathrm{W}: \varnothing)$

17. Utrum Beata Virgo fuit concepta in originali peccato. $\left(B^{58}\right.$ : ff. $64 r / 65^{*}-66 r / 67^{*}$; $C$ : $\varnothing$; F12: col. 131-133; O: Ø; P16: f.120r; W13: ff. 61rb-vb; Kaluza: p. 83)

18. Utrum positivum et privativum formaliter opponitur peccato. (B: ff. 66r/67*-68v/69*; C10: pp. 402a-404b; F15: col. 144-159; O6: ff. 215va-217ra; P14: f. 119v; W10: ff. 58vb60va; Bender: pp. 549-590; Kaluza: p. 82)

19. Utrum universum sit totum in toto et totum in qualibet parte. (B: ff. $68 \mathrm{v} / 69 *-69 \mathrm{v} / 70^{*}$; C11: pp. 405a-406b; F14: col. 139-143; O: Ø; P19: f. 120v; W14: ff. 63ra-va; Kaluza: p. 84)

20. Utrum ad omnem actionem cause secunde coefficientia prime cause necessario requiratur. (B: ff. 69/70*-73/74*; C: Ø; F7: col. 72-84; O3: ff. 213ra-vb; P6: f. 118v; W16bis ${ }^{59}$ : 22vb23rb; Kaluza: p. 79) ${ }^{60}$

21. Utrum sola voluntate absque omni alia ratione Deus alios reprobet, alios predestinet viatores (B: ff. 73/74*-73v; C: Ø; F19: col. 180-190; O: Ø; P12: f. 119v; W15: f. 63va ${ }^{61}$; Kaluza: p. 81)

Additiones of. Ms. F

\footnotetext{
57 sicut] sicus $B$

${ }^{58}$ In the middle of folio $65 \mathrm{v}$ there is a change in hands and the text continues in Rinfeldia's hand until the end of Aston's questions on f. 69v.

${ }^{59}$ Kaluza omits this question in his tabula compiled from W. Retaining his numbering, I will call this question W16bis.

${ }^{60} \mathrm{Th19}$ e attribution of this question is confirmed, as indicated by Kaluza, in the Responsiones of John Hiltalingen of Basel from Munich, Clm, 26711, f. 262va. As Kaluza remarked in Études doctrinales sur le XIVe siècle, p. 54, f. 3, Hiltalingen mentioned also: "Ad hoc faciunt Aston in isto articulo: Utrum ad omnem accionem cause secunde Dei coefficientia necessario requiratur...". A transcription of the question was made by Forte, $A$ Study of Some Oxford Schoolmen, II, pp. 142-158.

${ }^{61} \mathrm{In} \mathrm{W}$ there are 10 lines of the question and they are crossed out. Kaluza adds as Q. 16 the next title in the manuscript, which is actually Q. 7 of Book 2 of Richard FitzRalph. See on this above footnote XXX.
} 
F17, col. 168-172: Utrum unio distinctorum fit res aliqua que nec est illa nec aliquid illorum.

F18, col. 172-180: Utrum relations sint res vel non ${ }^{62}$.

F20, col. 190-200: Queritur utrum potentia volitiva hic in via eodem actu quo utitur creatura libere fruatur trinitate benedicta.

A synoptic conclusion on the relation between the titles of questions from different manuscripts of Nicholas Aston' questions from the Sentences can be summarized as follow:

\begin{tabular}{|c|c|c|c|c|c|}
\hline B & C & F & O & P & W \\
\hline 1 & 12 & 16 & 1 & 11 & Prol./Pricipium \\
\hline 2 & 1 & 1 & 11 & 1 & Prol., art. 1 \\
\hline 3 & 2 & 2 & 7 & 9 & Prol., art. 2 \\
\hline 4 & 3 & 3 & 8 & 2 & 3 \\
\hline 5 & 4 & 4 & 9 & 3 & 4 \\
\hline 6 & 8 & 9 & 5 & 8 & 6 \\
\hline 7 & 7 & 5 & 10 & 4 & 7 \\
\hline 8 & 6 & 6 & 4 & 5 & 5 \\
\hline 9 & $\varnothing$ & 8 & $\varnothing$ & 7 & 8 \\
\hline 10 & 9 & 10 & 2 & 18 & 13 \\
\hline 11 & 9 bis & 10 bis & 2 bis & $18 *$ & 13 bis \\
\hline 12 & 5 & 11 & $\varnothing$ & 10 & 9 \\
\hline 13 & $\varnothing$ & 15 & 12 & 15 & 11 \\
\hline 14 & $\varnothing$ & $\varnothing$ & $\varnothing$ & $\varnothing$ & $\varnothing$ \\
\hline 15 & $\varnothing$ & $\varnothing$ & $\varnothing$ & $\varnothing$ & $\varnothing$ \\
\hline 16 & $\varnothing$ & $\varnothing$ & $\varnothing$ & $\varnothing$ & $\varnothing$ \\
\hline 17 & $\varnothing$ & 12 & $\varnothing$ & 16 & 13 \\
\hline 18 & 10 & 15 & 6 & 14 & 10 \\
\hline 19 & 11 & 14 & $\varnothing$ & 19 & 14 \\
\hline 20 & $\varnothing$ & 7 & 3 & 6 & 16 bis \\
\hline 21 & $\varnothing$ & 19 & $\varnothing$ & 12 & 15 \\
\hline
\end{tabular}

\footnotetext{
${ }^{62}$ This question is missing in all the other manuscripts, except in the abbreviation of Gaudet, and Kaluza has shown (Études doctrinales sur le XIVe siècle, p. 81) that it is 'W prologus, art. 1'. See Bender's edition, p. 205: "In primo articulo declarabitur numquid relationes omnes sunt res vel non, quia magna est altercatio inter doctores de relationibus...".
} 